\title{
FARMERS' WILLINGNESS TO PAY FOR THE ECOSYSTEM SERVICES OF ORGANIC FARMING: A LOCALITY STUDY IN VALIKAMAM AREA OF SRI LANKA
}

\author{
SOORIYAKUMAR, K. ${ }^{*}$ - SiVASHANKAR, S. - SiREERANHAN, A. \\ Department of Agricultural Economics, Faculty of Agriculture, University of Jaffna, Sri Lanka \\ (phone: +94-21-206-0173; fax: +94-21-206-0175) \\ *Corresponding author \\ e-mail: kzs0008@tigermail.auburn.edu; phone: +94-76-320-3126; fax: +94-21-206-0175 \\ (Received 12 $2^{\text {th }}$ May 2019; accepted $28^{\text {th }}$ Aug 2019)
}

\begin{abstract}
This study investigates the farmers' willingness to pay for ecosystem services of organic farming in Valikamam area of Sri Lanka. Choice modeling employed indicates that farmers are willing to pay more for big reduction in nitrate leaching and soil quality improvement than biodiversity improvement. It indicates that farmers give more weight to the short term benefit than the long term sustainable benefit. Income and education level of farmers positively influence farmer's willingness to pay for soil quality improvement and Biodiversity. Young farmers are willing to pay more for soil quality improvement than old farmers. It shows that young farmers are willing to invest more to develop the farms than old farmers as young farmer value economic objective more than old farmers do. Middle aged farmers are willing to pay more for biodiversity. As middle aged farmers value social actions, environment responsibility more than young farmers do and are willing to invest more than old farmers do, middle aged farmers are willing to pay more for biodiversity than other farmers. Increasing farmer's income, organizing awareness programs on sustainable agriculture and providing subsidies could be the most effective ways to adopt organic farming in Valikamam.
\end{abstract}

Keywords: biodiversity, choice modeling, conditional logit model, nitrate leaching, soil quality

\section{Introduction}

Ecosystems provide a range of services which are very important to human wellbeing, livelihoods, health and survival. Ecosystem functions provide goods and services that satisfy human needs, directly or indirectly. Therefore, a growing human population and associated increasing food demands make the challenge to maintain and enhance ecosystem services in agriculture greater than in other ecosystems. Jaffna district in Sri Lanka is facing many problems such as high nitrate level in ground water, declining soil fertility, loss of biodiversity and declining crop productivity due to the overuse of agrochemical in agricultural production. Intensive agriculture that utilizes large quantities of inputs in the form of fertilizers, pesticide, labour and capital made it possible to grow enough food to meet the current global needs. However, these practices lead to environmental damage and degradation of several ecosystem services. Agro ecosystems not only provide ecosystem services but also consume them. Agro ecosystem is a highly managed ecosystem and provides food, forage, fiber, energy and pharmaceuticals. This agro ecosystem strongly depends on ecosystem services provided by natural ecosystem. Supporting ecosystem services comprise of genetic biodiversity for the use of breeding, soil formation, soil fertility, nutrient cycling and water purification (Sandhu et al., 2010). Regulating services include the services of pollinators and natural enemies (Power, 2010). 
As the economic value of ecosystem services is substantial, the utilization of these services for the long-term sustainability of agro-ecosystems and their ability to provide increased production while maintaining ecosystem services becomes very imperative (Sandhu et al., 2005). Sustainable agriculture seeks to make the best use of nature's goods and services while maintaining them for future generations. Organic agriculture is considered to be one of the production systems that aim to achieve sustainability by utilizing and maintaining ecosystem services. The estimated value of several ecosystem services is very high in organic agriculture than that of intensive agriculture. It is well known that organic agriculture delivers more environmental benefits than does intensive farming. Organic farming reduces the use of labour, fuel and agrochemicals and lowers external costs to human health and the environment (Sandhu et al., 2005). Scientists have been involved in enhancing the knowledge about how ecosystem services are produced for over a decade. Most studies had focused on estimating the value of one or two well understood ecosystem services. Better understanding of the processes of ecosystem could help to predict the range of ecosystem services from that ecosystem (Polasky, 2008). The valuation of ecosystem services generally includes both market and non-market valuation. Since agricultural commodities are traded in markets, valuing the provisioning services of agriculture is relatively simple.

Value of supporting services of ecosystems such as pollination services and biological control services can be estimated from in the quantity or quality of agricultural production when the services are removed or degraded (e.g. Losey and Vaughan, 2006; Gallai et al., 2009). Replacement cost method can be used to estimate the values of biological control as pesticides replace natural pest control and values of pollination services as hand-pollination replaces pollination by bees. Non-market valuation methods are used to estimate both the use value and the non-use value of various environmental amenities (Mendelsohn and Olmstead, 2009). Non-market valuation can be based on revealed preference or stated preference. In contingent valuation method, consumers are asked what they would be willing to pay for the ecosystem service. The goal of valuing ecosystem services is to use that information to form policies and incentives for sustainable management of ecosystems. There are difficulties in managing ecosystem services since many ecosystem services are public goods. Farmers' agronomic practices may strongly influence the ecosystem services available to others. Policy makers are facing challenges on how to use emerging information about ecological production functions and valuation to develop policies and incentives to achieve sustainable ecosystem management. In US and many European countries, incentives are provided to the farmers through government program to support for environmentally sound farming practices that support ecosystem services. The impacts of these programs are inconsistent, however, and their success is debated (e.g. Baulcombe et al., 2009).

Market imperfections of environmental goods and services distort their real prices or values and also consumers' willingness to pay on them cannot be readily observed. Market imperfections exist when public goods, externalities, and incomplete markets or property rights are involved (Baumol and Oates, 1975). Market imperfections have been categorized into public goods, externalities, and incomplete markets or property rights (Baumol and Oates, 1975). Since environmental resources produce benefits or costs for which markets do not provide an appropriate price, Market for these benefits and costs can be imperfect. Economic valuation methods generally can be divided into two broad categories: revealed preference methods and stated preference methods (Freeman, 
1993). Revealed preference methods depend on actual consumer behavior in the market. Stated preference method is used to estimate the value of non-market goods and services. In the stated preference method respondents were asked to state their preferences in one or more hypothetical scenarios (Mitchell and Carson, 1989). Stated preference methods could estimate both use and nonuse values. Use values are the monetary value of the utility derived from the direct or indirect consumption of a good or service. Nonuse values are less tangible and are naturally motivated by the wish to leave some existing assets to future generations.

Contingent valuation approach estimates respondent's maximum willingness to pay for a hypothetical change in an environmental good or service (Mitchell and Carson, 1989; Hanley et al., 2001). Conjoint analysis and choice modeling both value the multiple attributes of a product. Conjoint valuation analyzes one combination of attributes at a time. Choice modeling analyzes the values for multiple attributes of a product and their tradeoffs simultaneously (Merino-Castello, 2003). Multi-attribute techniques can be grouped into two categories: preference-based approaches, choicebased approaches. Preference-based approaches ask individuals to rate alternative scenarios on a cardinal scale, whereas choice-based approaches ask consumers to choose among alternative products on ordinal scale. Conjoint analysis is a technique that applied in marketing for many years, but it has recently been employed in economics (Louviere, 1991). The application of conjoint analysis to environmental economics is limited. Choice experiments have some advantages over contingent valuation methods.

In contingent valuation method, Respondents are asked to state their maximum willingness to pay for the improved good or service. The improvements in goods or services are needed to describe precisely. A problem arises in this approach is that if any errors in the information discovered after the fact cannot be changed. However, the choice experiment approach depends on the representation of a choice situation using a range of attributes. Therefore, it relies less on precise description of the good or service, but more on description of the situation. In choice experiment approach, respondents are asked about a sample of events drawn from the universe of possible events of that type (Louviere, 1994). Using attributes and levels of specific choice situations, choice modeling approach are used to make choice sets of attributes that reflect different states of the environment. Individuals are asked to choose their preferred alternative choice set from different choice sets. Thus, the choice modeling approach makes each individual tradeoff between the attributes of the situation. When a cost factor is included as one of attributes in a choice set, it becomes possible to estimate economic values of the other attributes. Choice modeling is attractive for environmental valuation because this type of analysis is based on random utility theory (McFadden, 1974; Ben-Akiva and Lerman, 1989).

The objectives of this study are to estimate the values of ecosystem services of organic farming such as reduction of nitrate leaching, improvement of soil quality improvement and biodiversity and make suggestions or recommendation to policy makers in local and central government to encourage organic farming in Valikamam area in Jaffna district. Intensive agriculture in Valikamam area created many environmental problems such as high nitrate level in ground water, declining of soil fertility, loss of biodiversity and declining crop productivity. Jaffna district is one of the districts in Sri Lanka that is endowed with significant natural and human resources that can be exploited for the agricultural purposes. The total land area including inland water 
is $1025.2 \mathrm{~km}^{2}$ (Jaffna District Secretariat, 2014). Jaffna district is divided into four sub divisions. They are Islands, Thenmarachi, Vadamarachi, and Valikamam. Total population of the district is around 600,000. Agriculture and fisheries have been the principle economic activities of the district. Agriculture sector is the leading sector and $1 / 3$ of the population mainly depends on agriculture. About 86,000 families are engaged in agriculture while 15,000 families engage in fishing. Agriculture in the district contributes substantially to the GDP of the country. Agriculture is the dominant productive sector in the Jaffna district. Figure 1 shows five divisional secretariats of Valikamam area: Valikamam East, Valikamam North, Valikamam South, Valikamam South west and Valikamam West. Total populations of those areas are 73087, 37579, 51099,52423 , and 48703, respectively. The climatic condition and the soil type of this area are conducive for the agricultural activities (Jaffna District Secretariat, 2014).

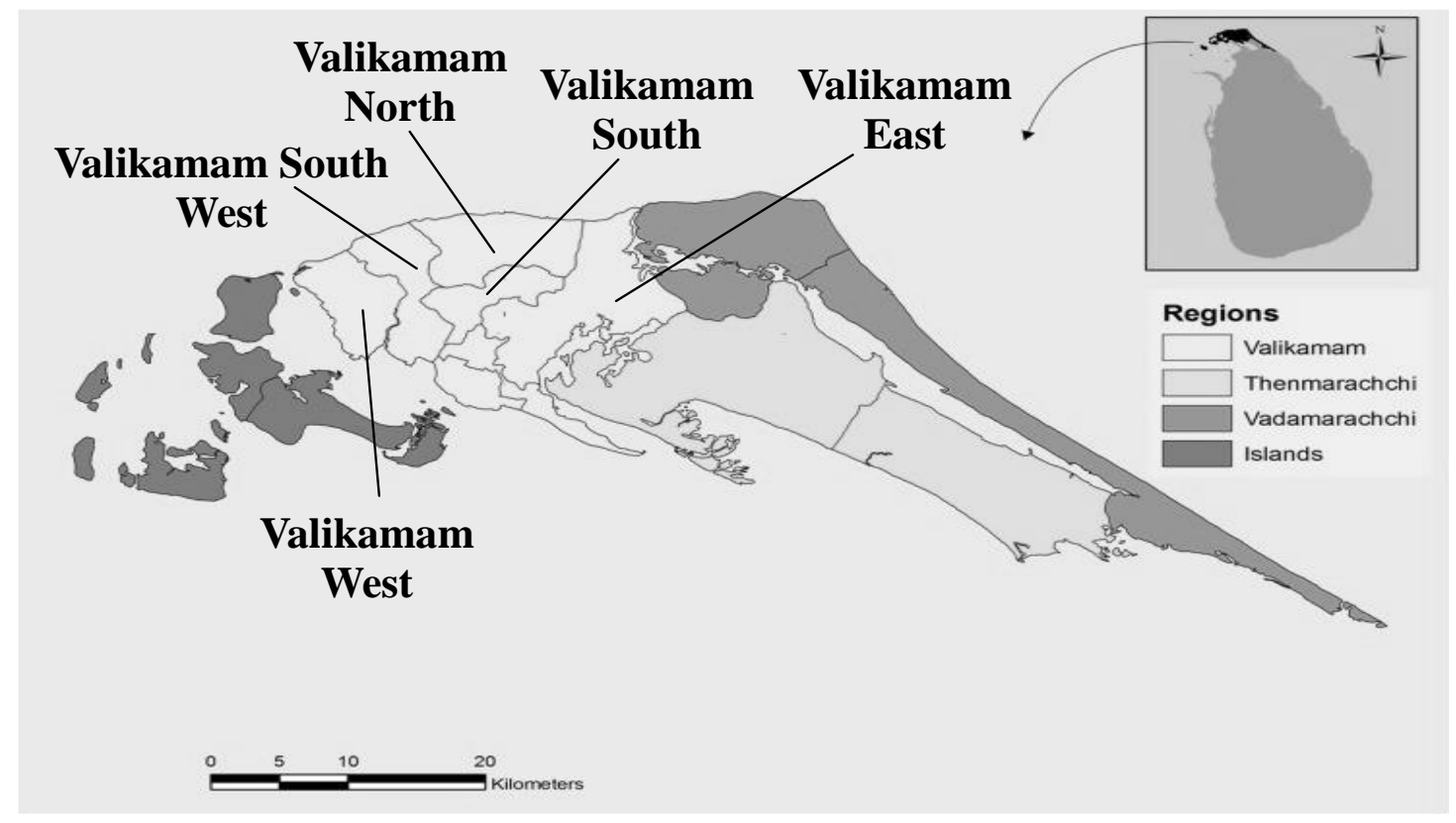

Figure 1. Map of Jaffna District

\section{Methodology}

Our primary aim is to assess marginal economic values of ecosystem services and benefits to the society; hence we employ choice modeling that is one of stated preference techniques. Discrete Choice Experiment (DCE) initially developed by Louviere and Hensher (1982) and Louviere and Woodworth (1983). The first application of a DCE in valuing environmental goods was reported by Adamowicz et al. (1994). In the recent years, the number of applications of choice modeling has significantly increased and become a popular stated preference method for environmental valuation. A complete summary of this valuation method can be found in Ben-Akiva and Lerman (1985), Louviere et al. (2000), Train (2003), Hensher et al. (2005) and Kanninen (2007). Choice modeling aims to assess the utility that individuals derive from the attributes of non-market environmental good or service under valuation. Choice modeling can also provide the opportunity to understand the trade-offs between different attributes (Adamowicz et al., 1998; Jin et al., 2006). 
Choice modeling was formulated in a random utility framework that permits measurement of the values of non-market goods and services. The Utility function (U) is a function of an observable component (indirect utility function) and an unobservable error component,

$$
U=V+\varepsilon
$$

where $\mathrm{V}$ is the indirect utility function and $\varepsilon$ is the stochastic error term. We assume that the indirect utility is a linear form,

$$
V_{i}=\beta_{i} X_{k i}+\alpha m=\beta_{1}+\beta_{2} x_{2 i}+\beta_{3} x_{3 i}+\ldots+\beta_{k} x_{k i}+\alpha_{i} m_{i}
$$

where $\left(X_{k i}=\left\{x_{1,2}, \ldots, x_{k}\right\}\right)$ is a vector of $\mathrm{k}$ attributes associated with alternative $\mathrm{i}, \beta$ is a coefficient vector, $\mathrm{m}_{i}$ is income for a respondent choosing the alternative $\mathrm{i}$ bundle, and $\alpha$ is the coefficient vector of income. If the stochastic error term is logistically Gumbel distributed (Type I extreme value distributed), the choice probability for alternative $i$ is given by

$$
\operatorname{Pr}(i)=\frac{\exp \left(\rho V_{i}\right)}{\Sigma_{j \in C^{\prime}}^{J}\left(\rho V_{i}\right)}
$$

where $\rho$ a positive scale parameter and $\mathrm{C}$ is is the choice set for an individual. For convenience we generally make the assumption $\rho=1$. To estimate willingness to pay for a change from the status quo state to the chosen state, the following formula is used:

$$
V_{i}\left(X_{i}, y\right)+\varepsilon_{i}=V_{j}\left(X_{j}, m-C V\right)+\varepsilon_{j}
$$

where $V_{i}$ and $V_{j}$ represent utility before and after the change and CV is compensating variation, the amount of money that makes the respondent indifferent between the status quo and the proposed scenario. Conditional logit model can be applied to estimate the welfare measure in Equation 4. Equation 4 can be restated as:

$$
\beta_{i} X_{k i}+\alpha_{i} m+\varepsilon_{i}=\beta_{j} X_{k j}+\alpha_{j}(m-C V)+\varepsilon_{j}
$$

$\alpha_{i}$ and $\alpha_{j}$ are assumed to be equal if marginal utility of income for a respondent is constant. The welfare change is estimated by:

$$
C V=-\frac{1}{\alpha}\left[\left(\beta_{i}\left(X_{k i}-X_{k j}\right)+\left(\varepsilon_{i}-\varepsilon_{j}\right)\right]\right.
$$

In conditional logit model, coefficient of $\mathrm{k}$ attributes across the all alternatives are the same, and $\beta_{i}=\beta_{\mathrm{j}}$; only the attribute levels differ across the alternatives. Under this condition, welfare change is estimated by the following:

$$
C V=-\frac{1}{\alpha}\left[\left(\beta\left(X_{k i}-X_{k j}\right)+\left(\varepsilon_{i}-\varepsilon_{j}\right)\right]\right.
$$


Equation 7 is used to estimate welfare changes in ecosystem services, assuming the impact of the attributes across the all alternatives same.

The attributes of selected ES provided by organic farming in this study were nitrate leaching, soil quality improvement, and biodiversity enhancement of organic farming. Each attribute has several discrete levels of delivery. For the nitrate leaching from organic farming, there were three levels present to respondents: big reduction $(50 \%$ reduction in nitrate leaching to ground water; small reduction $(20 \%$ reduction in nitrate leaching to ground water); and no change from current level of nitrate leaching to ground water. The attribute of soil quality of organic farming is limit to two level: soil quality improving and no change. The third attribute, biodiversity enhancement of organic farming is limit to two levels; more variety and no change.

The choice modeling surveys contain multiple choice sets about alternative policies for improving three ecosystem services. In the surveys, before the choice set questions, respondents were briefed about the three attributes of ecosystem services and associated cost to the household. The cost to the household, the payment vehicle, was defined as an additional annual payment to the regional office of environmental authority responsible for management of the environment. The discrete range of cost alternatives given to respondents was LKR 10, LKR 30, LKR 60, and LKR 100. In the choice questions, respondents were asked to select an option they favoured the most out of the three alternatives provided. Each option contains the three attributes and the cost to the household with various levels of attribute combinations. The cost to the household in option A was designed higher than in option $\mathrm{B}$, and option $\mathrm{C}$ was set as the status quo across all choice sets. Respondents were asked to answer similar types of choice questions sets multiple times. As there are three levels for nitrate leaching attributes, two levels in the soil and biodiversity attributes, and four levels in the cost to household, there are $2^{2} \times 3 \times 4$ factorial designs. For statistically efficient choice designs, a Defficient design excluding unrealistic cases was adapted to each of the choice questions. Definitions of selected Ecosystem Service Attributes on cropping farms are presented in Table 1. So 48 orthogonal choice combinations are possible but it is impossible to include the all the choices into to the questionnaire and impossible to ask the respondent to select the choice among the choice sets, so we reduce the number of choices in to half. We select 24 choice combinations among the 48 orthogonal combinations. Here we assume, interaction effects between attributes are insignificant. Among 24 choices, 3 unrealistic options were excluded, so 21 choices were selected. "No change" in the current attributes levels (Option C) was included in the each choice set. Levels of the attributes change from one alternative to the other except option C. Attributes, levels, payment of cost, organic farming benefits, and different levels of intensive organic farming are briefly introduced to the farmers during the survey. Each option in the choice set has different level of intensive organic farming. A sample of choices from 21 choices was given in the Appendix. In this study only four attributes with few levels were selected to reduce the number of choices and allows farmers to make a clear choice. After giving brief knowledge to the farmers individuals are asked to select the most preferred alternative among the choice sets. Conditional logit model was estimated for the selection of choices.

For this study, 107 farmers from Valikamam east and 104 farmers from rest of the Valikam area, a total of 211 farmers were randomly selected. Data were gathered from personal interviews with Farmers using structured questionnaire. Questionnaire include farmer's demographic and social characteristics such as age education, income, residents 
in rural or urban area and occupation, number of people in household, number of children, agricultural farming practices, environmental problems in their area and the 21 intensive organic farming management scenarios. Discrete choice modeling was used to estimate the economic value of three non-marketed ecosystem services: water quality improvement, soil quality improvement and Biodiversity enhancement associated with organic farming. Definitions of the effect codes for attributes and variable description are presented in Tables 2 and 3, respectively. Farmers' age and education level were categorized into 4 groups and income was classified into two groups.

Table 1. Definitions of selected ecosystem service attributes on cropping farms

\begin{tabular}{|c|c|c|}
\hline Attributes & Levels & Definitions \\
\hline Nitrate leaching & $\begin{array}{l}\text { Big reduction (NLB) } \\
\text { Small reduction (NLS) } \\
\text { No change }\end{array}$ & $\begin{array}{l}50 \% \text { reduction in nitrate leaching to ground water } \\
20 \% \text { reduction in nitrate leaching to ground water } \\
\text { Maintain current nitrate leaching to ground water }\end{array}$ \\
\hline Soil quality & $\begin{array}{l}\text { Improved (SQ) } \\
\text { No change }\end{array}$ & $\begin{array}{l}\text { Soil organic matter and structure are improved } \\
\text { Maintain current slow rate of soil degradation }\end{array}$ \\
\hline Bio diversity & $\begin{array}{l}\text { More variety (BD) } \\
\text { No change }\end{array}$ & $\begin{array}{l}\text { More variety of species on crop farms } \\
\text { Maintain current variety of species on crop Farms }\end{array}$ \\
\hline Cost to household & 10:30:60:100 & $\begin{array}{c}\text { Annual payment to a regional office (LKR) } \\
\text { Next five years }\end{array}$ \\
\hline
\end{tabular}

Table 2. Effect codes: choice modeling

\begin{tabular}{c|c|c}
\hline Attributes & \multicolumn{2}{c}{ Variables } \\
\hline \multirow{2}{*}{ Nitrate leaching } & NLB & 1 if big reduction; 0 if small reduction; -1 if no change \\
& NLS & 1 if small reduction; 0 if big reduction; -1 if no change \\
\hline Soil quality & SQ & 1 if improved; -1 if no change \\
\hline Biodiversity & BD & 1 if more variety; -1 if no change \\
\hline
\end{tabular}

Table 3. Variable description

\begin{tabular}{|c|c|c|}
\hline Variable & Description & Unit \\
\hline East & Valikamam East & 1 if Valikamam East; 0 if other areas \\
\hline Income1 & Income & $\begin{array}{l}1 \text { if monthly income is less than } 135 \text { USD }(20,000 \text { LKR) } \\
0 \text { if monthly income is } 135 \text { USD (20,000 LKR) and more }\end{array}$ \\
\hline Edu 1 & Education level & $\begin{array}{c}1 \text { if farmer's education is } \leq 5^{\text {th }} \text { grade } \\
\text { Otherwise } 0\end{array}$ \\
\hline Edu2 & Education level & $\begin{array}{c}1 \text { if } 5^{\text {th }} \text { grade }<\text { farmer's education } \leq 8 \text { th grade } \\
\text { Otherwise } 0\end{array}$ \\
\hline Edu3 & Education level & $\begin{array}{c}1 \text { if } 8^{\text {th }} \text { grade }<\text { farmer's education } \leq 11 \text { th grade } \\
\text { Otherwise } 0\end{array}$ \\
\hline Age 1 & Age & $\begin{array}{c}1 \text { if farmer's age is } \leq 40 \text { years } \\
\text { Otherwise } 0\end{array}$ \\
\hline Age 2 & Age & $\begin{array}{c}1 \text { if } 40 \text { years }<\text { farmer's age } \leq 55 \text { years } \\
\text { Otherwise } 0\end{array}$ \\
\hline Age 3 & Age & $\begin{array}{c}1 \text { if } 55<\text { farmer's age } \leq 65 \text { years } \\
\text { Otherwise } 0\end{array}$ \\
\hline
\end{tabular}




\section{Results and discussion}

The descriptive statistics of Valikamam east and rest of the Valikamam are given in Table 4. The descriptive statistics show that farmers from both places have almost similar statistics regarding income level and farmers age, but on average farmers from rest of the Valikamam have higher education level than the farmers from Valikamam East.

Table 4. Descriptive statistics

\begin{tabular}{c|c|c|c|c|c|c|c|c|c|c}
\hline Variable & \multicolumn{5}{|c|}{ East of Valikamam } & \multicolumn{5}{c}{ Rest of Valikamam } \\
\hline & Obs & Mean & Std. dev. & Min & Max & Obs & Mean & Std. dev. & Min & Max \\
\hline Income & 3,204 & 10981 & 7663 & 3000 & 45000 & 3,120 & 10782 & 7463 & 3000 & 50000 \\
Age & 3,204 & 53 & 11 & 30 & 82 & 3,120 & 53 & 11 & 27 & 80 \\
Education & 3,204 & 8.8 & 3.2 & 2 & 13 & 3,120 & 10 & 2.7 & 2 & 13 \\
\hline
\end{tabular}

Five conditional logit models were developed using effective codes for three ecosystem service attributes. Results of five conditional logit model were presented in Table 5. As a simple model, model 1 includes no social characteristics and no dummy values for divisional area of Valikamam and estimated as a simple pooled model. All variables except small reduction in nitrate leaching are significant at 5\% level. The negative coefficient of cost indicates that farmers are likely to accept the policy option with lower cost to them. Dummy values for Valikamam East and rest of the Valikamam are included in the Model 2 as interaction terms with each ecosystem service attribute. The interaction term of Valikamam East and biodiversity is negative and significant at 5\% level. It indicates that farmers from Valikamam east are willing to pay less for biodiversity than farmers from rest of Valikamam. Social characteristics such as income, education level and age are included in model 3, 4 and 5, respectively.

Mean welfare values from the improvement of each ecosystem service were estimated by using Equation 7 and the Estimated mean willingness to pay for each attribute were presented in Table 6. Mean welfare values of big reduction in nitrate leaching and soil quality improvement are almost similar between Valikamam east and rest of the Valikamam, which are around 0.53 USD (80 LKR) and 0.52 USD (79 LKR) per annum respectively. Farmers in Valikamam east give less weight for the improvement of biodiversity when compared to the farmers in rest of the Valikamam area. Farmers in Valikamam East and rest of the Valikamam are willing to pay for biodiversity improvement 0.1 USD (10 LKR) and 0.2 USD (30 LKR) per annum respectively. Mean welfare values of all three ecos ystem services in Valikamam East and rest of the Valikamam are 1.25 USD (188 LKR) and 1.05 USD (158 LKR) per farm household per year respectively. Farmers from both areas are willing to pay more for large reduction in nitrate leaching and soil quality improvement policies than the policy for biodiversity improvement. This result indicates that, for the farmers from both areas, the big reduction in nitrate leaching and soil quality improvement are more important than the improvement in biodiversity. This indicates that farmers give more weight to the short term benefit than the long term sustainable benefit. 
Table 5. Conditional logit model

\begin{tabular}{|c|c|c|c|c|c|}
\hline & Model 1 & Model 2 & Model 3 & Model 4 & Model 5 \\
\hline NLB & $0.565 * *$ & $0.562 * *$ & $0.644 * *$ & $0.711 * *$ & $0.639 * *$ \\
\hline NLS & -0.047 & -0.038 & 0.204 & 0.177 & 0.265 \\
\hline SQ & $0.435 * *$ & $0.433^{* *}$ & $0.636 * *$ & $0.789 * *$ & $0.628 * *$ \\
\hline $\mathrm{BD}$ & $0.228 * *$ & $0.258 * *$ & $0.254 * *$ & $0.369 * *$ & $0.236^{*}$ \\
\hline COST & $-0.016 * *$ & $-0.016^{* *}$ & $-0.016 * *$ & $-0.016^{* *}$ & $-0.016 * *$ \\
\hline East $\times$ NLB & & 0.013 & 0.012 & -0.045 & -0.043 \\
\hline East $\times$ NLS & & -0.033 & -0.036 & 0.003 & 0.007 \\
\hline East $\times \mathrm{SQ}$ & & -0.028 & -0.027 & -0.046 & -0.038 \\
\hline East $\times \mathrm{BD}$ & & $-0.152 * *$ & $-0.153 * *$ & $-0.167 * *$ & $-0.161 * *$ \\
\hline Income $1 \times \mathrm{NLB}$ & & & -0.09 & -0.061 & -0.002 \\
\hline Income $1 \times \mathrm{NLS}$ & & & $-0.274 * *$ & $-0.298 * *$ & $-0.320 * *$ \\
\hline Income $1 \times \mathrm{SQ}$ & & & $-0.227 * *$ & $-0.177 * *$ & $-0.163 * *$ \\
\hline Income $1 \times \mathrm{BD}$ & & & 0.009 & 0.042 & 0.025 \\
\hline Educa $1 \times \mathrm{NLB}$ & & & & 0.005 & 0.011 \\
\hline Educa $1 \times$ NLS & & & & -0.054 & -0.057 \\
\hline Educa1 $\times \mathrm{SQ}$ & & & & $-0.218 * *$ & $-0.206^{* *}$ \\
\hline Educa $1 \times$ BD & & & & $-0.209 * *$ & $-0.192 * *$ \\
\hline Educa $2 \times \mathrm{NLB}$ & & & & $-0.303 * *$ & $-0.290^{*}$ \\
\hline Educa $2 \times$ NLS & & & & $0.300^{* *}$ & $0.296^{*}$ \\
\hline Educa2 $\times \mathrm{SQ}$ & & & & $-0.231 * *$ & $-0.214 * *$ \\
\hline Educa2 $\times$ BD & & & & -0.088 & -0.075 \\
\hline Educa $3 \times$ NLB & & & & -0.051 & -0.074 \\
\hline Educa3 $\times$ NLS & & & & -0.011 & 0.009 \\
\hline Educa3 $\times$ SQ & & & & $-0.236^{* *}$ & $-0.252 * *$ \\
\hline Educa3 $\times$ BD & & & & $-0.186 * *$ & $-0.189 * *$ \\
\hline Age $1 \times$ NLB & & & & & 0.193 \\
\hline Age $1 \times$ NLS & & & & & -0.131 \\
\hline Age1 $\times$ SQ & & & & & $0.186^{* *}$ \\
\hline Age $1 \times \mathrm{BD}$ & & & & & 0.108 \\
\hline Age $2 \times$ NLB & & & & & 0.064 \\
\hline Age $2 \times$ NLS & & & & & -0.119 \\
\hline Age $2 \times$ SQ & & & & & $0.215^{* *}$ \\
\hline Age $2 \times \mathrm{BD}$ & & & & & $0.176^{* *}$ \\
\hline Age $3 \times$ NLB & & & & & -0.093 \\
\hline Age $3 \times$ NLS & & & & & -0.033 \\
\hline Age $3 \times$ SQ & & & & & 0.122 \\
\hline Age $3 \times \mathrm{BD}$ & & & & & $0.197 * *$ \\
\hline
\end{tabular}

**Significant at $1 \%$ level, *significant at $5 \%$ level

Table 6. Mean WTP per farming family per year USD (LKR)

\begin{tabular}{c|c|c|c}
\hline Area & NLB & SQ & BD \\
\hline Rest of Valikamam & $0.53(79.88)$ & $0.52(78.5)$ & $0.2(29.5)$ \\
Valikamam East & $0.5(74.50)$ & $0.49(73.8)$ & $0.06(9.38)$ \\
\hline
\end{tabular}


Total willingness to pay for these ecosystem services attributes can be calculated from the mean values. According to the Jaffna District statistics, there are about 12353 farming families from Valikamam East and 19450 families from rest of the Valikamam. Based on these numbers and estimated mean willingness to pay, the total WTP for each ecosystem services are estimated and presented in Table 7. Results of these models show that farmers who get monthly income less than 135 USD (20,000 LKR) are willing to pay less for soil quality of improvement than farmers who get monthly income more than 135 USD (20,000 LKR).

Table 7. Total WTP per farming family per year USD (million LKR)

\begin{tabular}{c|c|c|c}
\hline Area & NLB & SQ & BD \\
\hline Rest of Valikamam & $10400(1.56)$ & $10200(1.53)$ & $4000(0.6)$ \\
Valikamam East & $6133(0.92)$ & $6066(0.91)$ & $800(0.12)$ \\
Total & $16533(2.48)$ & $16266(2.44)$ & $4800(0.72)$ \\
\hline
\end{tabular}

The interaction term of education levels with Soil Quality and Biodiversity attributes are negative and significant at 5\% level. It indicates that farmers who have education level of $11^{\text {th }}$ grade or below are willing to pay less for soil quality improvement and Biodiversity than farmers who have education level above $11^{\text {th }}$ grade. The interaction terms of age with soil quality attributes is positive and significant at 5\% level. It indicates that farmers who are 55 years old or below are willing to pay more for soil quality improvement than who are above 55 years old. The interaction terms of age and biodiversity attributes indicates that farmers whose age is between 40 years and 65 years are willing to pay more for biodiversity than farmers whose age are below 40 years and above 65 years. These findings are consistent with the previous study which found that young farmers were the most active at developing their farms and old farmers were the least active. Young farmers value economic objective slightly more than old farmers, whereas they valued social actions, environment responsibility objectives less than did others (Rantamäki-Lahtinen and Väre, 2012).

\section{Conclusion}

Welfare values for changes in levels of three ecosystem services associated with organic farming were estimated using choice modeling method. Estimated mean willingness to pay for each attribute indicates that farmers from both areas are willing to pay more for large reduction in nitrate leaching and soil quality improvement policies than the policy for biodiversity improvement. Soil quality is directly linked to the agricultural productivity and farmers waste their economic resources due to strong nitrate leaching. Nitrate leaching increase the nitrate level in the ground water which is used as drinking water and causes health problem. Therefore, for farmers, the both big reduction in nitrate leaching and soil quality improvement became more important than the improvement in biodiversity. It also indicates that farmers give more weight to the short term benefit than the long term sustainable benefit.

Farmers from both places have almost similar statistics regarding income level and farmers age, but on average farmers from rest of the Valikamam have higher education level than the farmers from Valikamam East. Therefore, Farmers' unawareness about 
the benefits of biodiversity in Valikamam east might be one of the reasons for low willingness to pay for biodiversity improvement. Total willingness to pay for all three ecosystem services in rest of the Valikamam and Valikamam East are 24600 USD (3.69 million LKR) and 13000 USD (1.95 million LKR) per year respectively. It shows that there is a potential to impose minimal tax on farmers and provide this tax revenue as a subsidy to the farmers who practice organic farming. This will encourage more farmers to practice organic farming. Farmers with lower monthly income are willing to pay less for soil quality of improvement than farmers with higher monthly income. Farmers with lower education level are willing to pay less for soil quality improvement and Biodiversity than farmers with higher education level. Young farmers are willing to pay more for soil quality improvement than old farmers. Middle aged farmers are willing to pay more for biodiversity than young and old farmers. It indicates that young farmers are willing to invest more to develop the farm than middle aged and old farmers. As middle aged farmers value social actions, environment responsibility more than young farmers do and are willing to invest more than old farmers do, middle aged farmers are willing to pay more for biodiversity. This study concludes that creating opportunities to earn extra money from off-farm and on-farm economic activities and organizing awareness program on the benefits of reducing nitrate leaching and improving soil quality and biodiversity for farmers, especially young and middle aged farmers and providing subsidy to the farmers who practice organic farming from the tax revenue collected by Central Environmental Authority could be an effective way to adopt organic farming in Valikamam area.

\section{REFERENCES}

[1] Adamowicz, W., Louviere, J., Williams, M. (1994): Combining revealed and stated preference methods for valuing environmental amenities. - Journal of Environmental Economics and Management 26: 271-292.

[2] Adamowicz, W., Boxall, P., Williams, M., Louviere, J. (1998): Stated preference approaches for measuring passive use values: choice experiment and contingent valuation. - American Journal of Agricultural Economics 80: 64-75.

[3] Baulcombe, D., Crute, I., Davies, B., Dunwell, J., Gale, M., Jones, J., Ptetty, J., Sutherland, W., Toulmin, C. (2009): Reaping the Benefits: Science and the Sustainable Intensification of Global Agriculture. - The Royal Society, Policy Document 11/09, London.

[4] Baumol, W. J., Oates, W. E. (1975): The Theory of Environmental Policy. - Prentice Hall, Englewood Cliffs, NJ

[5] Ben-Akiva, M., Lerman, S. (1985): Discrete Choice Analysis. - MIT, Cambridge, MA.

[6] Freeman, A. M. (1993): The measurement of environmental and resource values: theory and methods. - Resources for the Future, Washington, DC.

[7] Gallai, N., Salles, J. M., Settele, J., Vaissière, B. E. (2009): Economic valuation of the vulnerability of world agriculture confronted with pollinator decline. - Ecological Economics 68: 810-821.

[8] Hanley, N., Mourato, A., Wright, R. (2001): Choice modeling approaches: a superior alternative for environmental evaluation? - J. Econ. Survey 15(3): 435-462.

[9] Hensher, D. A., Rose, J. M., Greene, W. H. (2005): Applied Choice Analysis. A Primer. Cambridge University Press, New York.

[10] Jaffna District Secretariat (2014): Jaffna District Statistical Handbook. - Jaffna District Secretariat, Sri Lanka.

[11] Kanninen, B. J. (ed.) (2007): Valuing Environmental Amenities Using Stated Choice Studies. - Springer, Dordrecht. 
[12] Losey, J. E., Vaughan, M. (2006): The Economic Value of Ecological Services Provided by Insects. - Bioscience 56: 311-323.

[13] Louviere, J. (1991): Best-Worst Scaling: A Model for the Largest Difference Judgments. - Working Paper, University of Alberta.

[14] Louviere, J., Hensher, D. A. (1982): On the design and analysis of simulated choice or allocation experiments in travel choice modelling. - Transportation Research Record 890: 11-17.

[15] Louviere, J., Woodworth, G. (1983): Design and analysis of simulated consumer choice or allocation experiments: an approach based on aggregate data. - Journal of Marketing Research 20: 350-367.

[16] Louviere, J., Hensher, D. A., Swait, J. (2000): Stated Choice Methods: Analysis and Applications. - Cambridge University Press, Cambridge.

[17] McFadden, D. (1973): Conditional Logit Analysis of Qualitative Choice Behavior. - In: Zarembka, P. (ed.) Frontiers in Econometrics. Academic Press, New York.

[18] Mendelsohn, R., Olmstead, S. (2009): The economic valuation of environmental amenities and disamenities: Methods and applications. - Annual Review of Environment and Resources 34: 325-347.

[19] Merino-Castello, A. (2003): Eliciting Consumer Preferences Using Stated Preference Discrete Choice Models: Contingent Ranking versus Choice Experiments. - Department of Economics and Business, Pompeu Fabra University, Barcelona, Spain. http://www.econ.upf.edu/docs/papers/downloads/705.pdf. - Accessed in May 2011.

[20] Mitchell, R., Cameron, R., Carson, T. (1986): The Use of Contingent Valuation Data for Benefit-Cost Analysis in Water Pollution Control. Final Report to the U.S. Environmental Protection Agency, September. - U.S. Environmental Protection Agency, Washington, DC.

[21] Polasky, S. (2008): What's nature done for you lately: measuring the value of ecosystem services. - Choices 23(2): 42-46.

[22] Rantamäki-Lahtinen, L. M., Väre, M. (2012): Strategic objectives and development plans of beginning farmers. - Agricultural and Food Science 21(4): 430-439.

[23] Sandhu, H. S., Wratten, S. D., Cullen, R., Hale, R. (2005): Evaluating nature's services on Canterbury arable farmland. Technical Report. - National Centre for Advanced BioProtection Technologies, Lincoln University, Lincoln.

[24] Sandhu, H. S., Wratten, S. D., Cullen, R. (2010): Organic agriculture and ecosystem services. - Environmental Science \& Policy 13: 1-7.

[25] Power, A. G. (2010): Ecosystem services and agriculture: tradeoffs and synergies. Philos. Trans. Roy. Soc. B 365: 2959-2971.

[26] Train, K. (2003): Discrete Choice Methods with Simulation. - Cambridge University Press, New York.

\section{APPENDIX}

1. Please tick the option that you most prefer

\begin{tabular}{|c|c|c|c|}
\hline & Option A & Option B & Option C \\
\hline Nitrate leaching & Big reduction & Small reduction & No change \\
\hline Soil quality & Improvement & No change & No change \\
\hline Biodiversity & More variety & More variety & No change \\
\hline $\begin{array}{c}\text { Payment for the option (Rs. } \\
\text { per year for next 5 years) }\end{array}$ & Rs. 100 & Rs. 10 & Rs. 0 \\
\hline
\end{tabular}

Option A

Option B

Option C 
2. Please tick the option that you most prefer

\begin{tabular}{|c|c|c|c|}
\hline & Option A & Option B & Option C \\
\hline Nitrate leaching & Big reduction & No change & No change \\
\hline Soil quality & No change & Improvement & No change \\
\hline Biodiversity & More variety & No change & No change \\
\hline $\begin{array}{c}\text { Payment for the option (Rs. } \\
\text { per year for next 5 years) }\end{array}$ & Rs. 100 & Rs. 10 & Rs. 0 \\
\hline
\end{tabular}

Option A

Option B

Option C

3. Please tick the option that you most prefer

\begin{tabular}{|c|c|c|c|}
\hline & Option A & Option B & Option C \\
\hline Nitrate leaching & Small reduction & Big reduction & No change \\
\hline Soil quality & Improvement & No change & No change \\
\hline Biodiversity & No change & More variety & No change \\
\hline $\begin{array}{c}\text { Payment for the option (Rs. } \\
\text { per year for next 5 years) }\end{array}$ & Rs. 100 & Rs. 60 & Rs. 0 \\
\hline
\end{tabular}

Option A

Option B

Option C 